\title{
Article \\ Effect of Aspect-Slope on the Growth of Conifers in a Harsh Boreal Climate of Northwest Sweden
}

\author{
Friday N. Ogana ${ }^{1, * \mathbb{C}}$, Fredrik Sjödin ${ }^{2}$, Emma Holmström $^{1}{ }^{\mathbb{D}}$, Clas Fries $^{3}$ and Urban Nilsson ${ }^{1}$ \\ 1 Southern Swedish Forest Research Centre, Swedish University of Agricultural Sciences, P.O. Box 190, \\ 23422 Lomma, Sweden; emma.holmstrom@slu.se (E.H.); urban.nilsson@slu.se (U.N.) \\ 2 Svartbergets Field Research Station, Swedish University of Agricultural Sciences, 92291 Vindeln, Sweden; \\ fredrik.sjodin@slu.se \\ 3 Swedish Forest Agency, P.O. Box 284, 90106 Umeå, Sweden; clas.fries@skogsstyrelsen.se \\ * Correspondence: friday.nwabueze.ogana@slu.se
}

check for updates

Citation: Ogana, F.N.; Sjödin, F.; Holmström, E.; Fries, C.; Nilsson, U. Effect of Aspect-Slope on the Growth of Conifers in a Harsh Boreal Climate of Northwest Sweden. Forests 2022, 13, 301. https://doi.org/10.3390/ f13020301

Academic Editor: Phillip G. Comeau

Received: 28 January 2022

Accepted: 10 February 2022

Published: 12 February 2022

Publisher's Note: MDPI stays neutral with regard to jurisdictional claims in published maps and institutional affiliations.

Copyright: (c) 2022 by the authors. Licensee MDPI, Basel, Switzerland. This article is an open access article distributed under the terms and conditions of the Creative Commons Attribution (CC BY) license (https:// creativecommons.org/licenses/by/ $4.0 /)$.

\begin{abstract}
Tree development is affected by different factors including topographic features. The effect could be even more complex in harsh environments such as in the northwest of Sweden. In this study, we analyzed the effect of aspect-slope on the development up to the age of 34 years of five species: black spruce, lodgepole pine, Norway spruce, Siberian larch and Scots pine. The species were planted in a field experiment on the southwest slope, mountaintop, and northeast slope in a randomized complete block design in the northwest of Sweden (latitude $67^{\circ}$ ) with $2 \mathrm{~m} \times 2 \mathrm{~m}$ spacing. No re-measurement data were available and, as such, retrospective diameters and heights were derived from sample discs and measurement of length to every branch whorl, respectively. Variations in tree survival rate, height and diameter were analyzed using a linear mixed-effect model. The results showed that there were significant $(p<0.05)$ differences between species in survival rate, diameter and height growth; in some cases, differences were found between contrasting aspect-slope. Black spruce and Siberian larch had the best survival rate under this harsh boreal climate. However, Siberian larch had the best growth and developed well on the mountaintop and northeast slope. Lodgepole pine developed well on the southwest slope. Scots pine also grew well on the southwest slope and mountaintop. Norway spruce had the slowest growth. Based on this study, Siberian larch and lodgepole pine can serve as alternatives to the two traditional conifer species, Norway spruce and Scots pine, used in Sweden. Siberian larch is particularly suitable because it is able to withstand the harshness of the boreal environment.
\end{abstract}

Keywords: Siberian larch; lodgepole pine; Scots pine; Norway spruce; black spruce; diameter and height growth; survival; harsh boreal climate

\section{Introduction}

Early seedling survival following planting strongly depends on the quality of the seedling microsite [1-3], which is determined by the interaction between biotic and abiotic factors $[4,5]$. Factors such as climate (precipitation, temperature, sunlight, etc.), competition (influence of other trees and ground vegetation) and topographic features (aspect, elevation and slope, etc.) affect seedling survival, regeneration and, to a large extent, the forest diversity [6,7]. Adverse environmental conditions reduce the chances of tree development [8]. The combination of high latitude, altitude and a north-facing slope have been reported to reduce growth and increase mortality [9].

Furthermore, topographic heterogeneity of a landscape can further condition the recruitment, survival and development of species [10], because two opposing aspects, e.g., north-facing and south-facing, may experience variations in sunlight, humidity, and temperature, and have different growing periods, even within a similar elevation [6]. For example, a significant difference in biomass between north-facing and south-facing slopes has been observed in northwest China [11]. In Africa, terrain slope has been reported to 
have a negative impact on the survival rate of Afzelia Africana [4]. Furthermore, studies have also shown that Mediterranean pine species have a high survival rate on north-facing compared to south-facing slopes because of lower radiation, which enhances cooler and mesic conditions $[10,12]$. A prolonged winter period often increases seedling mortality and reduces tree growth $[13,14]$, which makes forest regeneration difficult, especially in regions close to the 'treeline', such as the north-western part of Sweden. In the northernmost part of Sweden, as well as in the country, about $90 \%$ of the clear-felled area is planted and a very small proportion $(<5 \%)$ is regenerated by seedlings. The remaining area is naturally regenerated [15].

Sweden has three broad forest vegetation zones: the nemoral (in the south), hemiboreal (transition zone) and the boreal (south-central to northernmost) zones [16]. The Swedish forests are predominantly made up of two coniferous species-Scots pine (Pinus sylvestris) and Norway spruce (Picea abies), both in monoculture and mixed stands, with few broadleaved trees. This pair accounts for approximately $80 \%$ of the standing timber volume [16]. Lodgepole pine is non-native pine species planted in boreal Swedish from around 1970. Boreal forests are generally adapted to perturbations such as snow, flooding, windthrow, fungus infestations, and activities of beavers and defoliating insects [17,18]. Plantations in the northern boreal zone risk severe mortality and growth reduction due to the combination of harsh climate and biotic disturbances, e.g., Scots pine saplings are at risk of being damaged by Phacidium infestans under the snow and by ungulate browsing above the snow [19]. During winters with high snowpack, Gremmeniella abietina has caused damage to lodgepole pine in the region [20]. Norway spruce has repeatedly been proven to perform less well in terms of seedling growth during the first years of establishment [21,22]. At the northern boreal zone, for example, in the Gällivare region (latitude $67^{\circ} 29^{\prime} \mathrm{N}$ and longitude $20^{\circ} 30^{\prime} \mathrm{E}$ ), the mean annual temperature is $0.1^{\circ} \mathrm{C}$ and mean annual precipitation is around $600 \mathrm{~mm}$ [23]. It snows almost half of the year. The summer is short and there is 'midnight sun' for a substantial period in summer. This makes the region one of the harshest in Sweden that carries forests. The duration of the growing season is about 120 days [23]. Nonetheless, around 5-6 million cubic meters of the country's timber is obtained from Norrbottens county, which includes Gällivare [24].

Studies on the effect of aspect-slope (i.e., the slope's direction with reference to the sun) on the development of trees under harsh conditions from long-term experiments are not well documented in Sweden. A previous study on the influence of aspect on the initial growth of conifers' seedlings reported no significant variation in the survival rate of the species between contrasting slopes in northern Sweden, and only slight variation in dominant height [13]. Only a short observation period (3-4 years from planting) was used in the study. However, the author recommended at least 10 years of monitoring be undertaken before appropriate assessment of species' regeneration response to aspect-slopes under harsh conditions is possible because of protracted seedling mortality and other reasons [13]. Understanding how aspect-slope affects tree survival and development under prevailing harsh conditions will help in promoting its regeneration and establishment in a multifaceted landscape. Thus, this study seeks to provide answers to the following questions: In these harsh conditions, do aspect-slope effects on tree survival and development differ between species? Do we have any alternatives to the traditional two species Norway spruce and Scots pine? To answer these questions, we used five conifer species (Norway spruce, Scots pine, Siberian larch, lodgepole pine and black spruce) planted in a field experiment. We hypothesized that tree survival and growth are lower on the north-facing slope and mountaintop than on the south-facing slope, and that the effects vary between species.

\section{Materials and Methods}

\subsection{Study Area and Experimental Design}

The study was conducted at Gällivare in Sweden, about $100 \mathrm{~km}$ north of the Arctic Circle (Figure 1). The experiment was established in 1987 to study "whether survival and growth differ between seedlings planted on differently facing slopes, aspects of a mountain with harsh boreal climate". Three aspect-slopes (hereafter called A-S) were used 
in the experiment: the southwest slope (hereafter called SW), northeast slope (hereafter called NE), and the crest of the mountain Peltovaara (hereafter called Top). The mountain Peltovaara is situated at latitude $67^{\circ} 05^{\prime} \mathrm{N}$ and longitude $20^{\circ} 22^{\prime} \mathrm{E}$, with an altitude between 476 and $478 \mathrm{~m}$ above sea level (a.s.l). SW and NE range from 444 to $456 \mathrm{~m}$ a.s.l. [13]. The degree of slope at SW and NE ranged from 5 to $10 \%$, and was $0 \%$ at the Top [13]. The region has a cold climate because of its relatively high latitude. The mean daily temperature ranges from $-13.1{ }^{\circ} \mathrm{C}$ in January to $14.7^{\circ} \mathrm{C}$ in July; and in summer, the temperature can occasionally rise above $30^{\circ} \mathrm{C}[23]$.
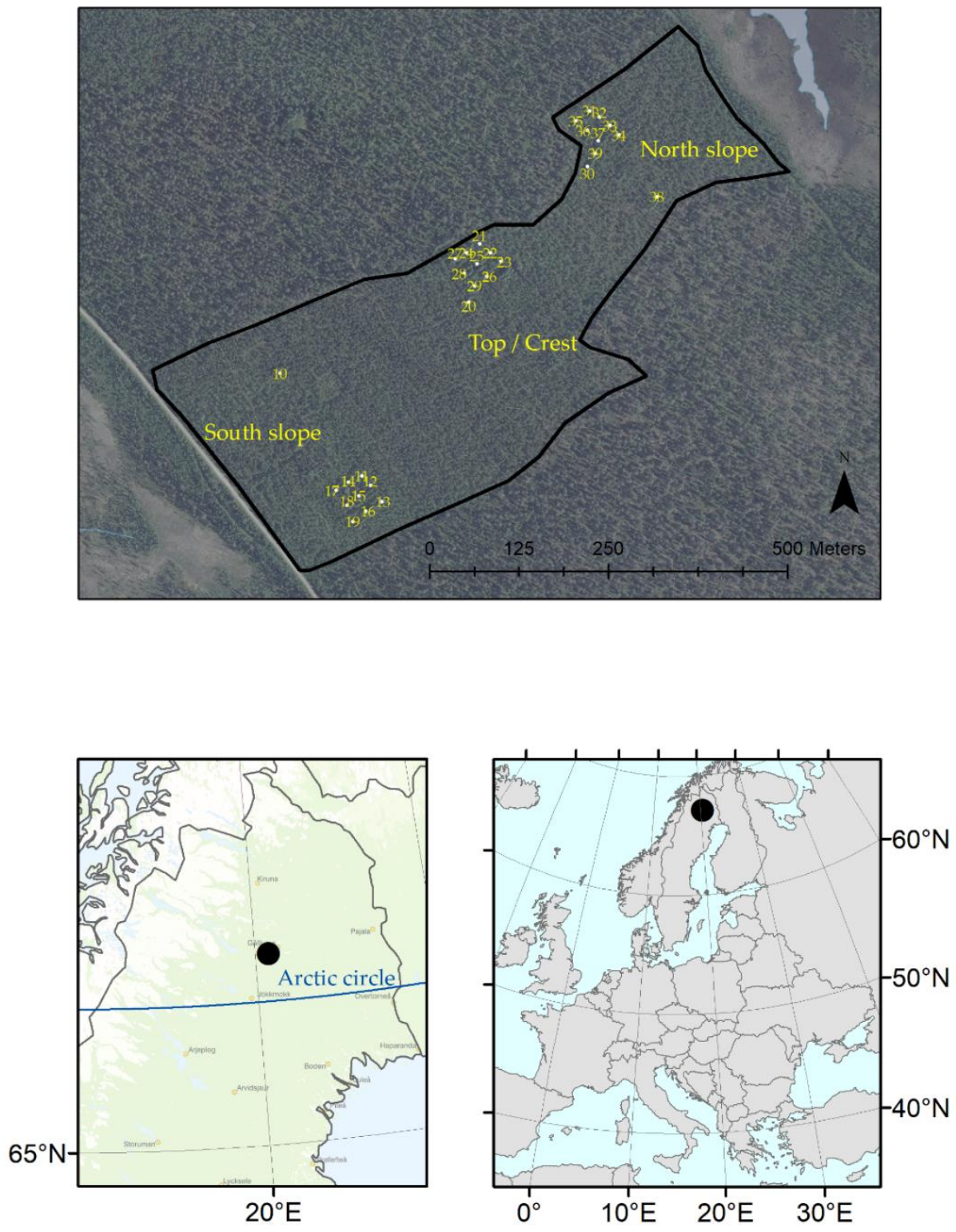

Figure 1. The Peltovaara experimental site (2405) with the distribution of the blocks (90 seedlings per block).

The same soil preparation (patch mounding) was undertaken for the three A-S (SW, Top and NE), with each mound around $0.2-0.3 \mathrm{~m}$ and containing $20-40 \mathrm{dm}^{3}$ of mineral soil [13]. At the commencement of the experiment in June 1987, the three sites were planted with one-year-old seedlings of Scots pine (Pinus sylvestris L., 3 provenances), SP; lodgepole pine (Pinus contorta Dougl. Ex Loudon), LP; and Siberian larch (Larix sibirica Ledeb.), SL. In addition, in June 1988, two-year-old seedlings of Norway spruce (Picea abies (L.) Karst., 3 provenances), NS; and black spruce (Picea mariana (Mill.) B.S.P.), BS, were planted. 
Within each site, 10 blocks of $20 \mathrm{~m} \times 18 \mathrm{~m}$ size were initially established, and each block consisted of nine rows. The seedlings ( 9 species $\times$ provenance combinations) were planted in mounds randomly on different rows with $2 \mathrm{~m} \times 2 \mathrm{~m}$ spacing (10 seedlings per row) [13]; 2700 seedlings in total were used for the experiment.

\subsection{Field Measurements}

A complete enumeration of the trees on the three A-S was carried out in the summer of 2020 (32/33 years after establishment). Information on diameter, tree species and status (alive or dead) was documented. However, only a few sample trees were measured for height. The information on species status was used to determine the tree survival rate as of the year 2020. Three sample blocks were selected from each A-S based on the density and species representation.

Three trees per species per block in each experimental site were randomly selected from the tree list (in total 135 trees). Before the selection of the sample trees, we carried out a preliminary analysis to check whether variation existed in the height curve at the provenance level (for Norway spruce and Scots pine). A variation, however non-significant, was found only for the Norway spruce provenances. We, therefore, decided not to use different height curves for Norway spruce and Scots pine at the provenance level.

The selected sample trees represent the range of the diameter distribution per species in each site for trees with $\mathrm{dbh} \geq 4.5 \mathrm{~cm}$. Sample trees were located, marked at $1.3 \mathrm{~m}$ breast height and felled from the base. Once on the ground, a measuring tape was used to measure the length to every branch whorl from the top to the base of the tree. Then, a $2 \mathrm{~cm}$ cross-sectional disc was obtained at breast height (the marked point) with a chain saw. The discs were labelled according to the tree number, species, plot and site, and taken to the dendrochronology laboratory for dendrochronological analysis. To avoid a rupture in the discs, the samples were oven-dried at a constant temperature of $60^{\circ} \mathrm{C}$ for two days. Thereafter, they were sanded to fine grit and scanned to a resolution of $1200 \mathrm{dpi}$ (2400 for smaller discs) with Epson Perfection V330 Photo. Tree rings were measured in CooRecorder integrated with the CDendro 9.6 program [25].

\subsection{Tree Growth Reconstruction}

The main purpose of reconstruction in this study was to obtain a database of tree species, site, year, dbh and height. For the sampled trees, we derived the retrospective diameter from the $2 \mathrm{~cm}$ disc at breast height. This information was used to fit a diameter growth function, from which the previous diameters of the remaining standing trees were derived. Separate functions were fitted for BS, LP, NS, SL and SP for each of the three A-S. The power function (Equation (1)) was used in this study. The choice of the number of sample trees is important for model parameterization, and a minimum of five trees has been previously suggested [26].

$$
d b h_{i}=b_{0} d b h_{2020}^{b_{1}}
$$

where $d b h_{i}$ represents the diameter at breast height at year $i$ in $\mathrm{cm} ; d b h_{2020}$ is the diameter at breast height at the last inventory $2020 ; b_{0}$ and $b_{1}$ are model parameters to be estimated. A similar function has been recently used for mixed stands [26]. The regression model was based on the assumption of a constant bark thickness over time.

In the case of retrospective height, the measured length between successive whorls per sampled tree was used to measure annual heights. Thus, with the information on the retrospective diameter and height growths, a database of A-S, tree species, diameter- and height-development was generated for all sample trees. To obtain the heights of all trees, the Näslund function [27] (Equation (2)) was fitted to the height and diameter data from the sampled trees per species per year for the individual A-S (SW, Top and NE), expressed as:

$$
h_{i}=1.3+\left(\frac{d b h_{i}}{b_{0} d b h_{i}+b_{1}}\right)^{3}
$$


where $h_{i}$ and $d b h_{i}$ are the individual tree height and diameter at year $i$, respectively; $b_{0}$ and $b_{1}$ are model parameters to be estimated. It was necessary to fit the model to the individual tree species and years because the parameters $b_{0}$ and $b_{1}$ vary with species and age of stand development $[26,28]$. A similar model specification has been used in Scots pine and Norway spruce in central Sweden $[29,30]$. The reconstructed tree growth data were used to study tree development from 2003 to the inventory in summer 2020. This information would increase the understanding if one species has become dominant over another species.

\subsection{Data Analysis}

Differences in survival rate and diameter and height of the species on the different A-S as of 2020 were analyzed using a linear mixed model (Equation (3)). The factors A-S (SW, Top and NE) and species, and the interactions, were regarded as the fixed effect, and block as the random effect. Data on survival rate (in \%) were transformed with arcsine before the analysis was performed to fulfil the assumption of normality. The results are, however, presented without the arcsine transformation. The additive model is expressed as:

$$
Y_{i j}=\mu+A-S_{i}+\text { Species }_{j}+\left(A-S \times \text { Species }_{i j}+\varepsilon_{i j}\right.
$$

where $Y_{i j}$ represents the response or dependent variables (survival rate, diameter and height); $\mu$ is the population mean; aspect-slope (A-S) and species (categorical variables) are the fixed effect, together with their interactions, representing the independent variables; $\varepsilon_{i j}$ is random error. Only the diameter and height of the dominant trees ( 3 trees) of each species per block were analyzed. A 5\% level of significance was used as the threshold for the analysis, and where significances were observed for a variable, a post hoc test using Tukey (HSD) was conducted to ascertain which factors differed. The fitting of the model was performed using the lmerTest package implemented in R [31].

\section{Results}

At tree age 35, SW presented better survival rates for all species except NS (Table 1). The lowest survival rates were observed on Top for most of the species, except for NS with a significantly high survival rate. The survival rate of LP on SW (72\%) was significantly higher than on NE and Top. Generally, BS and SL had the best survival rates across the three A-S, and the worst was observed in SP.

Table 1. Survival rate (\%) of black spruce (BS), lodgepole pine (LP), Norway spruce (NS), Siberian larch (SL) and Scots pine (SP) on the three A-S: SW, Top and NE.

\begin{tabular}{cccc}
\hline Species & SW & Top & NE \\
\hline BS & $89 \pm 3.8^{\mathrm{a}}$ & $84 \pm 3.7^{\mathrm{ab}}$ & $86 \pm 3.1^{\mathrm{ab}}$ \\
LP & $72 \pm 5.1^{\mathrm{a}}$ & $41 \pm 5.0^{\mathrm{b}}$ & $43 \pm 2.6^{\mathrm{b}}$ \\
NS & $38 \pm 3.7^{\mathrm{a}}$ & $51 \pm 3.4^{\mathrm{b}}$ & $40 \pm 3.8^{\mathrm{a}}$ \\
SL & $84 \pm 2.7^{\mathrm{a}}$ & $71 \pm 3.8^{\mathrm{a}}$ & $77 \pm 5.2^{\mathrm{a}}$ \\
SP & $36 \pm 3.2^{\mathrm{a}}$ & $30 \pm 3.5^{\mathrm{a}}$ & $22 \pm 2.9^{\mathrm{a}}$ \\
\hline
\end{tabular}

The values are mean \pm standard error $(n=10)$. Values with the same superscript in the same row are not significantly different.

The results from the analysis of the tree growth characteristics showed that little differences in diameter were observed between the three $A-S$ (SW, Top and NE) for the dominant trees. Only SL had a significantly higher diameter on Top, and SP had significantly lower diameter values on the NE site. Overall, SL presented higher diameter values and NS the lowest ones (less than half that of SL). In the case of tree height, significant differences were observed among SW, Top and NE (Figure 2B). Both BS and LP were significantly higher on SW. NS, SL and SP were significantly higher on Top. All species except BS had significantly lower height values on the NE. Generally, LP had greater height values and NS had the lowest of all species on all aspect-slopes in the experiment. 

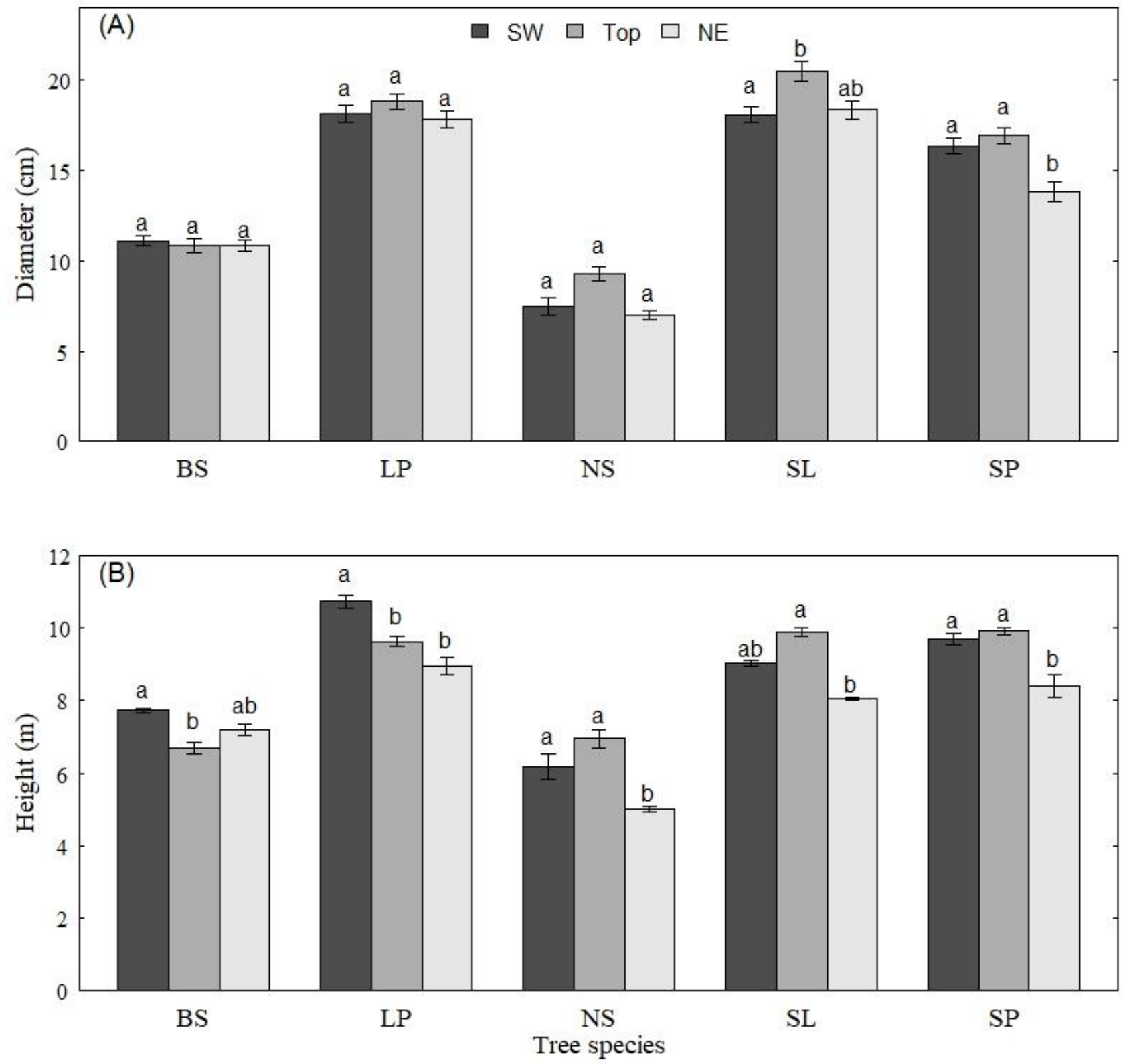

Figure 2. Comparison of the mean diameter (A, upper panel) and height (B, lower panel) of the dominant trees of black spruce (BS), lodgepole pine (LP), Norway spruce (NS), Siberian larch (SL) and Scots pine (SP) on the southwest slope (SW) mountaintop (Top) and northeast slope (NE). Means with the same letter are not significantly different $(p<0.05)$.

The diameter development of the species showed that BS and even more of NS developed poorly on SW, Top and NE (Figure 3A). SP was intermediate, and LP and SL performed similarly on the slopes. SL had the best diameter development on Top.

Similarly, for the height development, BS and NS grew poorly on all sites, particularly NS on NE (Figure 3B). SL and SP had the same development pattern on SW and NE. SL grew tallest on Top in a large part of the study period but grew equally well with SP towards the later stage. LP had the best height development on the contrasting slopes. BS started poorly at the early stage on Top but had a significant growth between 2005 and 2006, and thereafter had a consistent increment, with its position slightly below NS.

The shift in the height-diameter curves of the species in the last decade varied, especially on NE (Figure 4). NS had little difference between the years for SW and Top, 
whereas other species had little difference in NE but larger differences in Top and SW. SL had different height curves in all three aspects.

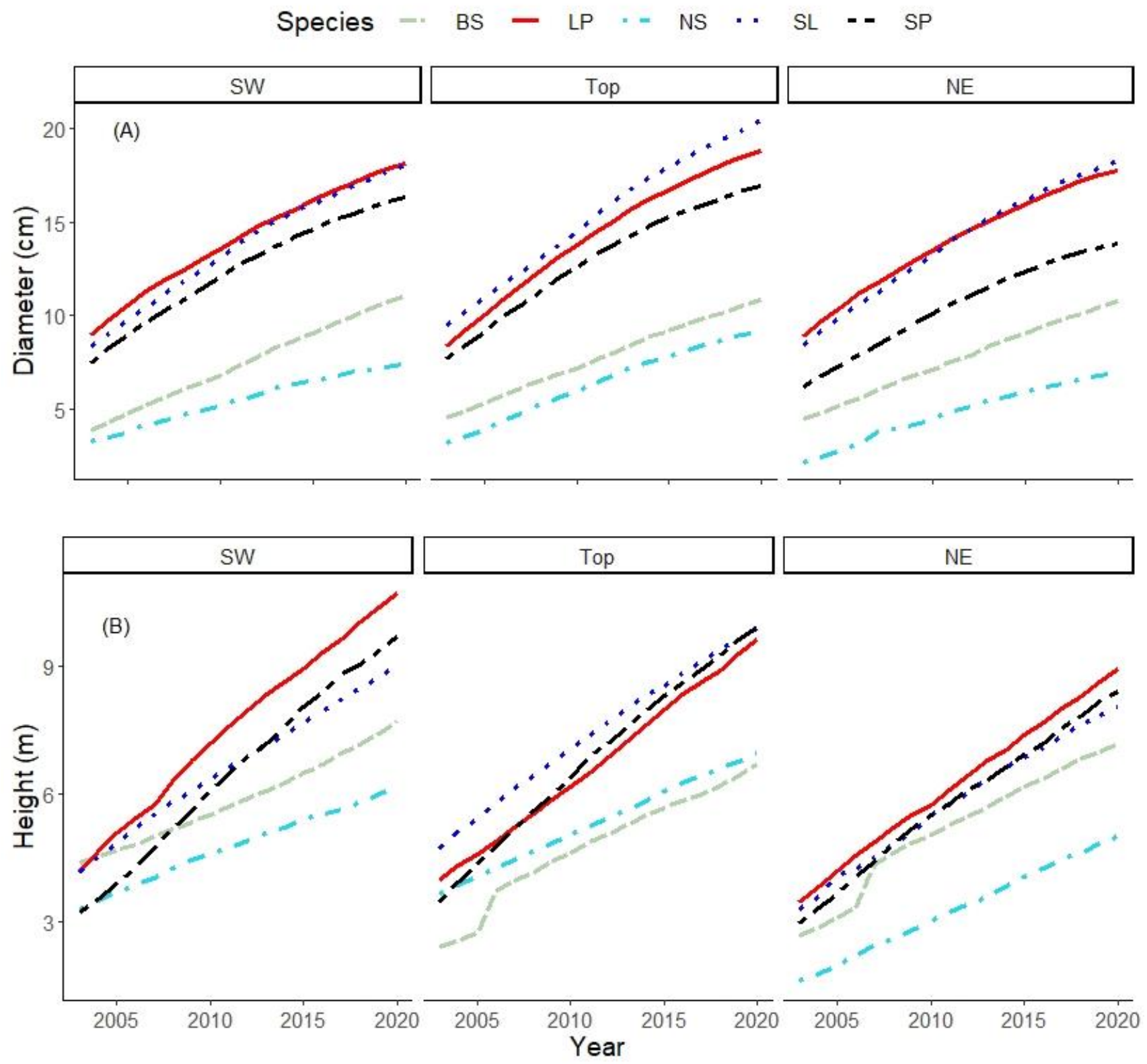

Figure 3. (A) Diameter and (B) height developments of the five species across the sites. 


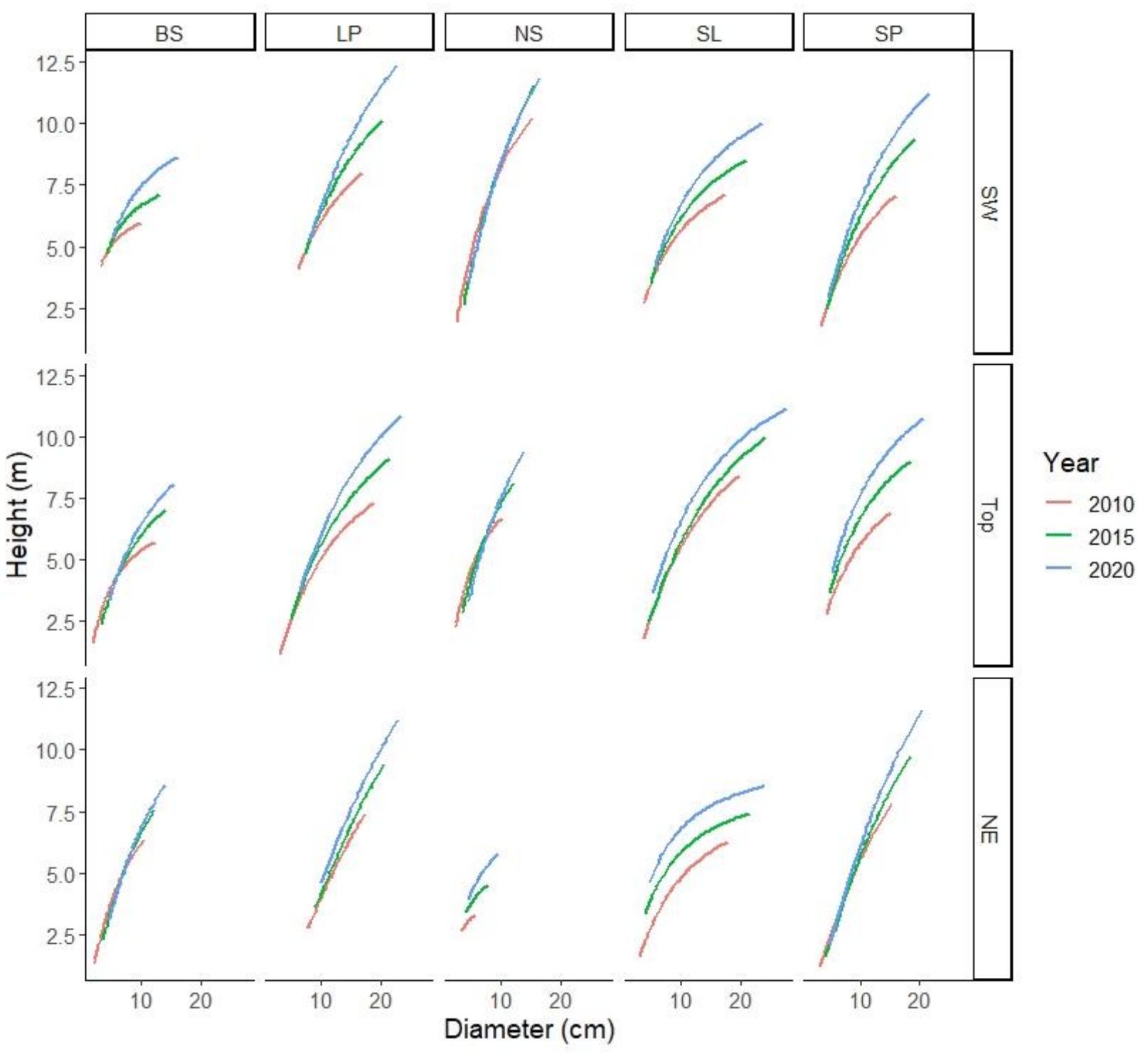

Figure 4. Shift in height-diameter curves of the species on the aspect-slopes in the last decade.

\section{Discussion}

This research evaluated the effect of aspect-slope on the survival and development of conifer species in harsh boreal climates. The survival rate, diameter and height growths of the species varied across the aspect-slopes. Our hypothesis of lower survival and growth on the northeast slope and mountaintop was true for some of the tree species.

The survival rate of black spruce, Siberian larch, lodgepole pine and Scots pine was higher on the southwest slope than on the northeast slope. The southwest slope also seems to favor the survival of most of those species compared to the mountaintop. One reason for this variability may be the high soil temperature on the southwest slope, and high snow and wind pressure on the northeast slope. Low soil temperature often limits root development $[13,32,33]$. A high snowpack in the northeast slope may be responsible for the low survival rate in some of the species, especially Scots pine, because the saplings are susceptible to Phacidium infestans attack under the snow [19]. The survival rate of Norway spruce was significantly higher on the mountaintop relative to the southwest, which implies that there may be other inherent factors influencing the survival of this species. Tree species, such as black spruce and Siberian larch, with high survival rates that were not significantly different on the southwest slope, mountaintop and northeast slope, could be raised at this latitude $\left(67^{\circ} \mathrm{N}\right)$ irrespective of the aspect-slope. A comparison of 
the initial survival rates of these species (3 years after establishment) [13] and the current survival rate (33 years after establishment) (Table 1), showed that only a few trees of black spruce and Siberian larch had died, especially on the southwest slope in the last 30 years (33-3). About 50\% of lodgepole pine died on the northeast slope and mountaintop during this period, in many cases probably due to damage by Gremmeniella abietina [20].

Height in 2020 was significantly greater at SW compared to NE for all tree species except Siberian larch. The diameter of Scots pine on the southwest slope was significantly larger than on the northeast slope, whereas diameter was not significantly different between A-S for other tree species. Height is a better measurement of growing condition than diameter, which is more greatly affected by competition. However, the mountaintop seems to favor the diameter and height growth of Siberian larch, Scots pine and Norway spruce compared to the opposite slopes. A similar observation has been reported the early stage of the stand development [13]. Moreover, a significant effect of aspect and slope on tree height development has been observed in Aleppo pine [34].

The results from the opposite slopes may be due to the difference in solar radiation and soil temperature [13,35]. Southwest slope receives higher solar radiation, which makes it warmer $[6,13]$ and, as such, more able to support tree growth under this harsh condition than the northeast slope. Conversely, the northeast slope is colder than the contrasting slope. Moreover, since Gällivare is considered to be an extremely harsh environment where there is snow cover for almost half of the year, it is most likely that snow is lying longer on the northeast slope than on the southwest slope. This increases mortality and reduces growth [14]. Other studies $[10,12,36]$ have reported greater growth and species diversity on north-facing slopes than south-facing slopes. This is expected in areas where moisture is a limiting factor because the increase in solar radiation increases evapotranspiration, which may induce drought and stress, and reduce tree growth [37-40]. However, for a region such as northern Sweden, moisture is not a limiting factor. South-facing slopes are generally richer in nutrients than north-facing slopes [41,42].

There was no explanation of why some of the species performed better on the mountaintop site than on the southwest slope. A previous study on the climatic variations of the three aspect-slopes indicated that the southwest slope was warmer than the mountaintop [13,43]. Tree growth is influenced by different factors, including neighborhood competitors [28,44-46] and climate [44,47,48]. However, by using the same region, block size and shape, number of species, planting pattern (random), density and age, we tried to eliminate any possible source of variation other than those being investigated, i.e., aspectslope and species. Moreover, if two contrasting slopes receive a varying amount of sunlight or radiation, then it is the topography that influences this variation [6]. Other site factors, such as soil type, may be responsible for this variation.

The diameter growth of Siberian larch and lodgepole pine dominated that of Scots pine, black spruce and Norway spruce on the contrasting slopes and mountaintop. The Siberian larch outgrew lodgepole pine on the northeast slope and had a superior growth on the mountaintop. Siberian larch is a frost-hardy species characterized by extremely thick and rough bark, which helps to reduce snow pressure on the stem compared to the other species. In addition, it is the only conifer among those investigated that sheds its needles in autumn and, as such, may not be susceptible to winter burn [49]. Norway spruce had poor diameter growth on all sites, which invariably will result in low volume production. Its average diameter was $<10 \mathrm{~cm}$ after 33 years of establishment. This further confirms that Norway spruce is not the most efficient species for wood production in the northernmost part of Sweden, where the weather condition is regarded as harsh [50].

In terms of height development, lodgepole pine had the best height growth on the slopes, especially the southwest slope, whereas Siberian larch had better development on the mountaintop. Scots pine had a consistent growth pattern on all sites. Generally, height development on the northeast slope was low. Damaged leading shoots were previously reported to be more frequent on the northeast slope [13] and, as a result, the author projected that future tree development on this site would be lower relative to other sites. This is true 
at least for lodgepole pine, for which evidence of broken tops was noticed on the northeast slope during disc extraction. Generally, snow damage to trees has been reported to be dependent on the interaction of topography and species [51].

\section{Conclusions}

This study showed that, under a harsh boreal climate, aspect-slope affects tree species' survival and development. Southwest slopes favor the survival and height growth of most of the species. Combined with survival, diameter and height growths of each species, it is valid to say that alternatives exist to the traditional two species-Norway spruce and Scots pine-in northern Sweden. Siberian larch and lodgepole pine are good alternatives when considering wood production. In this experiment, Siberian larch demonstrated that it is a species able to withstand the harshness of the boreal environment more than the other species examined.

Author Contributions: Conceptualization, F.N.O. and E.H.; methodology, F.N.O. and E.H.; formal analysis, F.N.O.; data curation, F.N.O. and F.S.; writing-original draft preparation, F.N.O.; writing-review and editing, F.N.O., F.S., E.H., U.N. and C.F.; supervision, E.H. and U.N.; project administration, E.H.; funding acquisition, E.H. All authors have read and agreed to the published version of the manuscript.

Funding: This research was funded under the Trees for Future (T4F) project.

Data Availability Statement: Not applicable.

Acknowledgments: The authors are thankful to Nicola Moré for assisting during the laboratory work.

Conflicts of Interest: The authors declare no conflict of interest.

\section{References}

1. Holmstrom, E.; Galnander, H.; Petersson, M. Within-site variation in seedling survival in Norway spruce plantations. Forests 2019, 10, 181. [CrossRef]

2. Nilsson, U.; Luoranen, J.; Kolström, T.; Örlander, G.; Puttonen, P. Reforestation with planting in northern Europe. Scand. J. For. Res. 2010, 25, 283-294. [CrossRef]

3. Sikström, U.; Hjelm, K.; Hanssen, K.H.; Saksa, T.; Wallertz, K. Influence of mechanical site preparation on regeneration success of planted conifers in clearcuts in fennoscandia-A review. Silva Fenn. 2020, 54, 1-35. [CrossRef]

4. Atanasso, J.A.; Mensah, S.; Salako, K.V.; Tohoun, R.J.; Glèlè Kakaï, R.; Assogbadjo, A.E. Factors affecting survival of seedling of Afzelia africana, a threatened tropical timber species in West Africa. Trop. Ecol. 2021, 62, 443-452. [CrossRef]

5. Uriarte, M.; Muscarella, R.; Zimmerman, J.K. Environmental heterogeneity and biotic interactions mediate climate impacts on tropical forest regeneration. Glob. Chang. Biol. 2018, 24, e692-e704. [CrossRef]

6. Maren, I.E.; Karki, S.; Prajapati, C.; Yadav, R.K.; Shrestha, B.B. Facing north or south: Does slope aspect impact forest stand characteristics and soil properties in a semiarid trans-Himalayan valley? J. Arid Environ. 2015, 121, 112-123. [CrossRef]

7. Paudel, S.; Vetaas, O.R. Effects of topography and land use on woody plant species composition and beta diversity in an arid Trans-Himalayan landscape, Nepal. J. Mt. Sci. 2014, 11, 1112-1122. [CrossRef]

8. Schroter, D.; Cramer, W.; Leemans, R.; Prentice, I.C.; Araujo, M.B.; Arnell, N.W.; Bondeau, A.; Bugmann, H.; Carter, T.R.; Gracia, C.A.; et al. Ecology: Ecosystem service supply and vulnerability to global change in Europe. Science 2005, 310, $1333-1337$. [CrossRef]

9. Moren, A.-S.; Perttu, K.L. Regional Temperature and Radiation Indices and Their Adjustment to Horizontal and Inclined Forest Land; Swedish University of Agricultural Sciences: Uppsala, Sweden, 1994; Volume 19, ISBN 91-576-4915-4.

10. Martínez-García, E.; Miettinen, H.; Rubio, E.; García-Morote, F.A.; Andrés-Abellán, M.; López-Serrano, F.R. Effects of post-fire management practices and slope-aspect on medium-term Spanish black pine regeneration: Implications of using a direct seeding strategy in burnt areas. Eur. J. For. Res. 2018, 137, 527-540. [CrossRef]

11. Hu, S.; Ma, J.; Shugart, H.H.; Yan, X. Evaluating the impacts of slope aspect on forest dynamic succession in Northwest China based on FAREAST model. Environ. Res. Lett. 2018, 13, 34027. [CrossRef]

12. Martín-Alcón, S.; Coll, L. Unraveling the relative importance of factors driving post-fire regeneration trajectories in non-serotinous Pinus nigra forests. For. Ecol. Manag. 2016, 361, 13-22. [CrossRef]

13. Fries, C. Aspects of Forest Regeneration in a Harsh Boreal Climate; Swedish University of Agricultural Sciences: Umeå, Sweden, 1991; ISBN 91-576-4470-5.

14. Malmqvist, C.; Wallertz, K.; Johansson, U. Survival, early growth and impact of damage by late-spring frost and winter desiccation on Douglas-fir seedlings in southern Sweden. New For. 2018, 49, 723-736. [CrossRef] [PubMed] 
15. Swedish Forest Agency. Statistical Database of Forestry. 2019. Available online: https://www.skogsstyrelsen.se/en/statistics/ statistical-database/ (accessed on 7 February 2022). (In Swedish)

16. Swedish Forest Agency. Forest Management in SWEDEN Current Practice and Historical Background; The Swedish Forest Agency: Jönköping, Sweden, 2020. Available online: https:/ / www.skogsstyrelsen.se/globalassets/om-oss/rapporter/rapporter-202120 2020192018/rapport-2020-4-forest-management-in-sweden.pdf (accessed on 7 February 2022).

17. Esseen, P.-A.; Ehnström, B.; Ericson, L.; Sjöberg, K. Boreal Forests. Ecol. Bull. 1997, 46, 16-47.

18. Saucier, J.P.; Baldwin, K.; Krestov, P.; Jorgenson, T. Boreal forests. In Routledge Handbook of Forest Ecology; Peh, K.S.-H., Corlett, R.T., Bergeron, Y., Eds.; Routledge: London, UK; New York, NY, USA, 2015; p. 23. ISBN 9781315818290.

19. Hansson, P.; Karlman, M. Survival, height and health status of 20-year-old pinus sylvestris and pinus contorta after different scarification treatments in a harsh boreal climate. Scand. J. For. Res. 1997, 12, 340-350. [CrossRef]

20. Karlman, M.; Hansson, P.; Witzell, J. Scleroderris canker on lodgepole pine introduced in northern Sweden. Can. J. For. Res. 1994, 24, 1948-1959. [CrossRef]

21. Nilsson, O.; Hjelm, K.; Nilsson, U. Early growth of planted Norway spruce and Scots pine after site preparation in Sweden. Scand. J. For. Res. 2019, 34, 678-688. [CrossRef]

22. Nilsson, U.; Elfving, B.; Karlsson, K. Productivity of Norway spruce compared to scots pine in the interior of Northern Sweden Silva Fenn. 2012, 46, 197-209. [CrossRef]

23. SMHI Yearly and Monthly Statistics. Available online: http://www.smhi.se/klimatdata/meteorologi/temperatur/2.1240 (accessed on 20 September 2021).

24. Nilsson, P.; Roberge, C.; Fridman, J. Forest Statistics 2021; Swedish University of Agricultural Sciences: Umea, Sweden, 2021.

25. Larsson, L.-Å. CDendro. 2020. Available online: http://www.cybis.se/forfun/dendro/index.php (accessed on 3 December 2021).

26. Heym, M.; Bielak, K.; Wellhausen, K.; Uhl, E.; Biber, P.; Perkins, D.; Steckel, M.; Andreas Thurm, E.; Rais, A.; Pretzsch, H. A New Method to Reconstruct Recent Tree and Stand Attributes of Temporary Research Plots: New Opportunity to Analyse Mixed Forest Stands. In Conifers; Gonçalves, A.C., Ed.; IntechOpen: London, UK, 2018; p. 21. ISBN 978-1-78984-801-4.

27. Petterson, H. Barrskogens volymproduktion. Medd. Fran Statens Skogsforskningsinstitut 1955, 45, 391.

28. Pretzsch, H. Forest Dynamics, Growth and Yield; Springer: Berlin/Heidelberg, Germany; Freising, Germany, 2009; ISBN 978-3-54088306-7.

29. Holmström, E.; Goude, M.; Nilsson, O.; Nordin, A.; Lundmark, T.; Nilsson, U. Productivity of Scots pine and Norway spruce in central Sweden and competitive release in mixtures of the two species. For. Ecol. Manag. 2018, 429, 287-293. [CrossRef]

30. Lidman, F.D.; Holmström, E.; Lundmark, T.; Fahlvik, N. Management of spontaneously regenerated mixed stands of birch and Norway spruce in Sweden. Silva Fenn. 2021, 55. [CrossRef]

31. R Core Team R: A Language and Environment for Statistical Computing. R Foundation for Statistical Computing, Vienna, Austria Available online: https:/ / www.r-project.org/ (accessed on 10 August 2021).

32. Alvarez-Uria, P.; Körner, C. Low temperature limits of root growth in deciduous and evergreen temperate tree species. Funct. Ecol. 2007, 21, 211-218. [CrossRef]

33. D'Orangeville, L.; Houle, D.; Duchesne, L.; Phillips, R.P.; Bergeron, Y.; Kneeshaw, D. Beneficial effects of climate warming on boreal tree growth may be transitory. Nat. Commun. 2018, 9, 3213. [CrossRef] [PubMed]

34. Omary, A. Al Effects of aspect and slope position on growth and nutritional status of planted Aleppo pine (Pinus halepensis Mill.) in a degraded land semi-arid areas of Jordan. New For. 2011, 42, 285-300. [CrossRef]

35. Salekin, S.; Mason, E.G.; Morgenroth, J.; Bloomberg, M.; Meason, D.F. Hybrid height growth and survival model for juvenile Eucalyptus globoidea (Blakely) and E. bosistoana (F. Muell) in New Zealand. For. Ecol. Manag. 2021, 490, 119074. [CrossRef]

36. Gong, X.; Brueck, H.; Giese, K.M.; Zhang, L.; Sattelmacher, B.; Lin, S. Slope aspect has effects on productivity and species composition of hilly grassland in the Xilin River Basin, Inner Mongolia, China. J. Arid Environ. 2008, 72, 483-493. [CrossRef]

37. Rotzer, T.; Biber, P.; Moser, A.; Schäfer, C.; Pretzsch, H. Stem and root diameter growth of European beech and Norway spruce under extreme drought. For. Ecol. Manag. 2017, 406, 184-195. [CrossRef]

38. Allen, C.D.; Macalady, A.K.; Chenchouni, H.; Bachelet, D.; McDowell, N.; Vennetier, M.; Kitzberger, T.; Rigling, A.; Breshears, D.D.; Hogg, E.H.; et al. A global overview of drought and heat-induced tree mortality reveals emerging climate change risks for forests. For. Ecol. Manag. 2010, 259, 660-684. [CrossRef]

39. Bigler, C.; Bräker, O.U.; Bugmann, H.; Dobbertin, M.; Rigling, A. Drought as an inciting mortality factor in scots pine stands of the Valais, Switzerland. Ecosystems 2006, 9, 330-343. [CrossRef]

40. Camarero, J.J.; Gazol, A.; Sangüesa-Barreda, G.; Oliva, J.; Vicente-Serrano, S.M. To die or not to die: Early warnings of tree dieback in response to a severe drought. J. Ecol. 2015, 103, 44-57. [CrossRef]

41. Fu, B.J.; Liu, S.L.; Ma, K.M.; Zhu, Y.G. Relationships between soil characteristics, topography and plant diversity in a heterogeneous deciduous broad-leaved forest near Beijing, China. Plant Soil 2004, 261, 47-54. [CrossRef]

42. Sidari, M.; Ronzello, G.; Vecchio, G.; Muscolo, A. Influence of slope aspects on soil chemical and biochemical properties in a Pinus laricio forest ecosystem of Aspromonte (Southern Italy). Eur. J. Soil Biol. 2008, 44, 364-372. [CrossRef]

43. Odin, H.; Löfvenius, M.; Aman, K. Klimatstudier pa ett Nordligt Högläge; Stencil 12: Uppsala, Sweden, 1990.

44. Aldea, J.; Ruiz-Peinado, R.; del Río, M.; Pretzsch, H.; Heym, M.; Brazaitis, G.; Jansons, A.; Metslaid, M.; Barbeito, I.; Bielak, K.; et al. Species stratification and weather conditions drive tree growth in Scots pine and Norway spruce mixed stands along Europe. For. Ecol. Manag. 2021, 481, 118697. [CrossRef] 
45. Pretzsch, H. Genetic diversity reduces competition and increases tree growth on a Norway spruce (Picea abies [L.] KARST.) provenance mixing experiment. For. Ecol. Manag. 2021, 497, 119498. [CrossRef]

46. Holmström, E.; Carlström, T.; Goude, M.; Lidman, F.D.; Felton, A. Keeping mixtures of Norway spruce and birch in production forests: Insights from survey data. Scand. J. For. Res. 2021, 36, 155-163. [CrossRef]

47. Oboite, F.O.; Comeau, P.G. Climate sensitive growth models for predicting diameter growth of western Canadian boreal tree species. For. An Int. J. For. Res. 2021, 94, 363-373. [CrossRef]

48. Vacek, Z.; Prokupkova, A.; Vacek, S.; Bulusek, D.; Simunek, V.; Hajek, V.; Kralicek, I. Mixed vs. monospecific mountain forests in response to climate change: Structural and growth perspectives of Norway spruce and European beech. For. Ecol. Manag. 2021, 488, 119019. [CrossRef]

49. Zhou, P.; Huang, J.G.; Liang, H.; Rossi, S.; Bergeron, Y.; Shishov, V.V.; Jiang, S.; Kang, J.; Zhu, H.; Dong, Z. Radial growth of Larix sibirica was more sensitive to climate at low than high altitudes in the Altai Mountains, China. Agric. For. Meteorol. 2021, 304-305, 108392. [CrossRef]

50. Yang, Q.; Blanco, N.E.; Hermida-Carrera, C.; Lehotai, N.; Hurry, V.; Strand, Å. Two dominant boreal conifers use contrasting mechanisms to reactivate photosynthesis in the spring. Nat. Commun. 2020, 11, 1-12. [CrossRef] [PubMed]

51. Tavankar, F.; Lo Monaco, A.; Nikooy, M.; Venanzi, R.; Bonyad, A.; Picchio, R. Snow damages on trees of an uneven age in mixed broadleaf forests: Effects of topographical conditions and tree characteristics. J. For. Res. 2019, 30, 1383-1394. [CrossRef] 